\title{
Topic of interest form middle upper level studentes: new spaces of opportunity
}

\section{Temas de interés para estudiantes de nivel medio superior: nuevos espacios de oportunidad}

\author{
SESENTO, Leticia’ \& LUCIO, Rodolfo" \\ 'Colegio Primitivo y Nacional de San Nicolás de Hidalgo, Mexico. \\ "Universidad Michoacana de San Nicolás de Hidalgo, Faculty of Veterinary Medicine and Zootechnics. Mexico.
}

ID $1^{\text {st }}$ Author: Leticia, Sesento / ORC ID: 0000-0002-6456-058X, Researcher ID Thomson: S-6997-2018, CVU CONACYT ID: 449302

ID $1^{\text {st }}$ Coauthor: Rodolfo, Lucio / ORC ID: 0000-0002-0535-3652, Researcher ID Thomson: X-2391-2018, CVU CONACYT ID: 947303

DOI: $10.35429 / J E H W .2020 .6 .4 .1 .9$

Received January 10, 2020; Accepted June 30, 2020

\begin{abstract}
The present investigation shows the results of a study carried out in the development of the Fourth Tutoring Expo. The objective was to identify the topics of interest to the students attending the tutoring activities. The work was developed under a quantitative approach. To collect information, a survey was used in which the impression of the event on the students who attended was measured; They were asked to write the topic (s) they would like to see taught at the next event to train teachers. 152 attendees of the Fourth Tutoring Expo, of both sexes, were surveyed. It is a descriptive quantitative investigation. It was a survey designed by the coordination of tutorials to learn about the topic of interest to be addressed in the following events. 152 attendees of the Fourth Tutoring Expo were surveyed, through a simple random sampling of participants of the event of both sexes. The results show that the topics of greatest interest are: $11 \%$, feminism, $11 \%$, Study techniques, $11 \%$, Contraceptive methods, $11 \%$, Gender equality, $10 \%$ How to be a good tutor and learn, $7 \%$, Infections sexually transmitted. It would be interesting to know the reasons why young students focus their attention on these topics to design a comprehensive action plan and thus clear up their doubts that lead us to adequately improve their development. Finally, it is important that teaching practices be re-signified from the tutorial activity, the institutional climate and collaborative work are the central aspects that are required to be contained in the development and training of this substantial instrument for young people.
\end{abstract}

Areas, Opportunity, Tutoring, Upper secondary education
Resumen

La presente investigación muestra los resultados de un estudio elaborado en el desarrollo de la Cuarta Expo Tutoría. El objetivo fue identificar los temas de interés para los estudiantes asistentes en las actividades de tutoría. El trabajo se desarrolló bajo un enfoque cuantitativo. Para la recolección de información se utilizó una encuesta en la que se midió la impresión del evento en los estudiantes que asistieron; se les solicitó escribir el o los temas que les gustaría que se les impartiera en el próximo evento para capacitar a los docentes. Se encuestó a 152 asistentes a la Cuarta Expo Tutoría, de ambos sexos. Es una investigación cuantitativa de tipo descriptivo. Fue una encuesta diseñada por la coordinación de tutorías con el objetivo de conocer sobre el tema de interés para abordarse en los siguientes eventos. Se encuestaron a 152 asistentes de la Cuarta Expo Tutoría, mediante un muestreo aleatorio simple a participantes del evento de ambos sexos. Los resultados muestran que los temas de mayor interés son: $11 \%$, feminismo, $11 \%$, Técnicas de estudio, $11 \%$, Métodos anticonceptivos, $11 \%$, Equidad de género, $10 \%$ Como ser un buen tutor y aprender, 7\%, Infecciones de transmisión sexual. Sería interesante el conocer las razones por las cuales los jóvenes estudiantes centran su atención en dichas temáticas para diseñar un plan de acción integral y así despejar sus dudas que nos lleven a mejorar adecuadamente su desarrollo. Para finalizar, es importante que las prácticas docentes, se resignifique de la actividad tutorial, el clima institucional y el trabajo colaborativo son los aspectos centrales que se demandan contener en el desarrollo y capacitación de este sustancial instrumento para los jóvenes.

Áreas, oportunidad, tutoría, educación media superior

Citation: SESENTO, Leticia \& LUCIO, Rodolfo. Topic of interest form middle upper level studentes: new spaces of opportunity. Journal Health, Education and Welfare. 2020. 4-6:1-9.

\footnotetext{
* Correspondence to Author (Email: leticiasesentogarcia@yahoo.com.mx)

$\dagger$ Researcher contributing first author.
} 


\section{Introduction}

Higher secondary education in Mexico in recent years shows a decrease in terminal efficiency, a consequence of dropping out and failure with low percentages of students entering the undergraduate degree. This problem arises from a decrease in the quality of educational services, poor management conditions and unfavorable personal situations of the students, so academic tutoring is an alternative, which facilitates the student's adaptation to the school context. For this reason, institutional academic tutoring programs have been shown in upper secondary education institutions, focused on reducing failure and school backwardness, reducing the dropout rate and improving terminal efficiency.

In the current situation of violence in our country, young people are exposed to greater dangers and risks. Parents, in turn, are overwhelmed by their professional work, predestining less time to observe how their children are developing and how they are building their personality, their values, their abilities. Difficulties are shown both in official and private schools.

Academic tutoring resides in the accompaniment and individualized educational support, for a better understanding of the difficulties of the student in relation to their accommodation to the school context, to the particular circumstances for a favorable exercise during their training and in support of the academic objectives, the responsibilities of your future professional experience. In Mexico, one of the main problems is high rates, disorientation and drug addiction among young people at the upper middle level.All this behavior appears from childhood due to a lack of love, care and communication caused mainly by family disintegration, which induces in the child and later young a disoriented development.

All the difficulties that the student has in the studies the lack of attention, the emotional instability, the aggressive behavior and laziness are being noticed in a complicated world and in certain occasions it is not known why, the student does not want to study a little to the exams, until it causes definitive withdrawal.
Hence the importance of continuous training programs and the evaluation of tutoring programs that are essential for progress and offer support in the different spaces that the student demands, thereby favoring comprehensive training and the particular advancement of students. students. For this reason, the present work aims to know the main concerns of the students for the development of the 5 th. Expotutoría in the aspects of workshops and presentations.

\section{Justification}

Higher Secondary Education requires promoting academic and individual development to provide students with the precise tools to enter Higher Education.

For this reason, the Tutoring aims to originate a series of works focused on strengthening the integral development of students, through individualized monitoring from the moment they enter the Baccalaureate, even when they finish this educational level, to support them in solving or channeling their difficulties academic, pedagogical or particular that arise in the training process at this educational level, so that absenteeism, desertion, failure, school violence, among other problems in relation to the student's context are reduced.

According to Luz Arévalo León, tutoring is one of the professions of educators pointed out for locating and affirming the integral development of students as well as an aid to reduce school problems (failure, dropout and lag). Within the tutoring, it is intended to regularize the specialized attention to the student, when so required, to assist with it the impulse of assertive psychological methods that admit to finding solution options to present and future conflictive contexts, that manage to violate their academic and personal training .

Academic tutoring has a humanistic orientation by concentrating its attention on the subject to motivate the development of their potentialities. This process is aimed at bringing about the integral advancement of students, without losing sight of the fact that each individual possesses qualities, abilities and weaknesses that distinguish them from others, and therefore make them unique. 
Teachers through tutoring have the opportunity to provide a comprehensive and effective education, which breaks the traditional paradigm present in most classrooms: few learning and knowledge challenges outside the context of real life. Teachers require alternatives to facilitate students learning and to motivate them. From this perspective, it is interesting to strengthen both the mastery of content for educators and the quality of educational interactions in the classroom through tutoring.

Academic tutoring in teaching practice and collaboration networks show serious actions to bring about progress in students. Learning from others always forms a reliable bet. The integral formation corresponds to involve perceptible learning; in experiential practices for students. This essentially involves a link with the students' daily life and with the universe. outline challenges or complications before starting a new topic; link the content of the class with events concerning the students (that they know from their context); and help students to transfer the subject to events or contexts present in the real world, investigating conceptions that involve significant experiences.

\section{Problem}

Currently the Higher Secondary Education Institutions face various challenges not only academic, but also social, personal and family of young people, which impacts their performance and academic development.

The challenge predominates with the increase in risk behaviors among EMS students. During the years they study EMS (Upper Secondary Education), young people challenge different scenarios of insecurity and often embrace behaviors that are contradictory to their well-being. In this regard, the Violence, Tolerance and Exclusion Survey, conducted in 2013 at EMS campuses, indicates that:

- Approximately one in four EMS students perceived violence or bullying.

- About $35 \%$ of the students have tried tobacco and $50 \%$ have had alcoholic beverages at some point.

- Just over 12 percent of EMS students have smoked marijuana at some point in their early life and even about 3\% have already tried cocaine.
- $\quad$ There are a significant number of sexually active young people (around 35\%); Of this total, just over one in five $(22 \%)$ does not use the appropriate means of prevention, which by chance can lead to unexpected pregnancies or sexually transmitted diseases, issues that are related to school dropout.

That is why, based on the needs of the students, the Institutions and specifically the Tutoring Coordination must train their tutors in different topics that arise in their environment, likewise, the importance of measures such as the one shown here to provide support to the teacher who has already detected the area of opportunity with his tutor and seeks training to be able to serve him.

\section{Objectives}

\section{General Objective}

Know the topics of interest to those attending the 4th. Expo Tutoring of young people of Upper Secondary Education.

\section{Theoretical framework}

\section{The beginning}

As of the 2009-2010 School Cycle, the General Directorate of the Baccalaureate gathered in its curriculum the basic elements of the Comprehensive Reform of Upper Secondary Education whose intention is to invigorate and strengthen the identity of this educational level, in all its modalities and subsystems ; provide a pertinent and relevant education to the student that allows her to establish a correspondence between the university and its context; facilitate the academic transit of students between the subsystems and the schools.

In relation to the above, the Tutoring arises, which, intends to prevent the difficulties of lag and dropout, seeks to increase the indexes of terminal efficiency, through works focused on optimizing the climate of harmony in the schools and addressing academic difficulties of the students. 
This implies favoring academic improvement, originating thought methods, taking steps, solving complications, the sense of commitment in students, as well as invigorating the impulse of competences through integration, feedback from the educational process, student motivation and academic support, through the intervention of the individual committed to the Tutorial Action by promoting the acquisition of learning to cement a life plan (DGB, 2012). It is important to note that in the first year of high school, the highest percentage of failure and dropout is recognized. To solve this, tutoring programs are demanded to prevent, discover and attend to learning, personal, family, economic, drug addiction, alcoholism or violence problems through intervention or support strategies.

Tutoring for students of this academic level, tries to represent an individualized accompaniment, that is, this work describes the attention that an educator trained as a tutor performs on the student, with the intention that he achieve his full impulse, in terms of his development , maturity, the expression of attitudes of responsibility and freedom. Based on these principles, the tutorial work allows perceiving a preference towards personalized attention by a teacher who has a greater capacity to support student learning (Romo, 2011).

\section{Concept}

Tutoring as the role of the university teacher is justified from the beginning of the University. In university tutoring, the figure of the tutor posed to the teacher in charge of the tutelage of a group of students on whom a variety of pedagogical actions were practiced, in order to be aware of the constancy of the knowledge taught. Tutoring was born, from the beginnings of the university, as an accompanying activity to the student different from the scientific or didactic role: the tutor was a union of scientific authority and a private advisor that alerted and confirmed the intellectual, social and oral behavior of their ward (Lázaro, 2003 cited by Cited in González, 2017, p3). The teacher is the student's tutor as he accompanies and guides his training, however, the understanding of how he practices his tutorial role is subordinate to the university model.
The National Association of Universities and Institutions of Higher Education (2001) proposes a definition of tutoring indicated as: "a process of accompaniment during the training of students, which is specified through personalized attention to a student or a small group of students, on the other hand, they are competent and trained academics for this function, conceptually relying on theories of learning rather than those of teaching "(p. 23).

In our country, this concept presented a huge footprint and is reflected as the "official" definition of tutoring in higher education. Arbizu Bakaikoa, Lobato Fraile and del Castillo (2005) specified the tutoring as a work of formative intervention proposed to the follow-up of the students and that is estimated as an action of the teacher. For their part, De la Cruz Flores, García Campos and Abreu Hernández (2006) describe it as the "formative process of a socio-cognitive nature, personalized and aimed at turning novices into competent individuals, through their integration into communities of practice and networks of experts, who solve problems in dynamic and complex environments, create and recreate professional action and, where appropriate, generate advanced knowledge "(p. 1367).

Herrera Aponte (2006) exposes it as a "dialectical, interactional, intersubjective process, where feelings and knowledge converge in a game of emotions and language. Mentoring as an accompaniment process is a task of shared commitments and responsibilities. To be successful, trust, communication, understanding and respect from both parties must be combined (p.200).

In 2008, the Center for Educational Research and Documentation (Spain) recovered various definitions of the concept, concluding that, based on them, "the importance of tutoring as a complementary part of the teaching work can be pointed out, since its purpose is The main thing is to facilitate the teaching-learning processes of the students and contribute to their personal, professional and social development "(p. 211).

Tutoring in Higher Secondary Education today unfolds in a flexible way and adapts to each of the students in relation to their personality, benefits, knowledge, abilities, level of problems and progress. 
The educational model increasingly attends to the particularities of the student in a personalized way, intervenes within a grouped education system, mainly if we take into account the challenge that is shown to us in the XXI century: a University that seeks curricular creativity, in a together with the development in intellectual and scientific production of application, both in the formation of knowledge and in the manufacture, services and an educational teaching process where the student rescues a role of subject-object, permanent in the pedagogical elements: learning to learn, learn to know, learn to act and do, learn to be, learn to live together.

Tutoring is conceived as a part of the teaching commitment, in which an individualized interaction is formed between the teacher and the student, with the aim of guiding their learning, accommodating it to individual conditions and their learning style, so that each student achieve the highest level of mastery possible. In this context, the tutor can be specified as the teacher who supervises the human and scientific training of a student and accompanies him in his learning processes.

\section{Tutor}

According to Arbizu Bakaikoa, Lobato Fraile and del Castillo (2005), the role of the tutor will depend on the affiliated tutoring model. In the comprehensive tutoring model, the role of the tutor resides in the following roles:

Consider, together with the student himself, his skills and academic performance of the student in order to guide him appropriately towards a training plan.

- $\quad$ Provide academic information to the student and monitor and monitor their learning methods.

- Guide the student in the foundation and management of their own learning.

- Carry out research and orientation tasks on academic, professional and labor world aspects.

- Guide the student in her professional direction.
- Promote continuous and occupational training of the student.

- Attend and perceive students who have certain problems of their own that affect their academic performance.

- Attend in a particular way the student who requires help.

- Develop in the student her opportune discernment, self-esteem, the progress of social skills.

- $\quad$ Teach the student in values.

\section{Tutored}

Every student, who takes guidance and monitoring of their process, academic performance and affective partner through a tutor from their entry, in each school period and even until their graduation. Either in individualized attention or as part of a group, it should be noted that the role of school institutions is aimed at helping students in their development and, therefore, they are the fundamental recipient of tutorial work.

From the perspective focused on learning, it allows to clarify with greater accuracy the need to install the energies in obtaining the graduation profile designed by RIEMS and the plan of the State General Baccalaureate program.

Based on the students, according to the environment and particularities of each institution, they are expected to assume:

- Take responsibility with their tutor for the progress of actions that are agreed jointly and be aware that the only person responsible for their training process is the student herself.

- $\quad$ To propose the methods of evaluation of the tutorial work, in relation to the determined institutional devices.

- Notice the additional activities that originate within the tutorial program. 


\section{Types of tutoring}

For the purpose pursued, which is the comprehensive development of students, tutoring at the General State Baccalaureate schools must be of the first type:

- Preventive. When working on aspects that, in the long run, can influence the learning process and therefore the student's adaptation. The schools tutorial action plan (PAT) corresponds to involve preestablished actions that are used in a general way for this function.

This type of tutoring has a Diagnostic period, in which we try to reveal those personal or group deficiencies in which it is necessary to intervene; proposes to use remedial tutoring, which is shown individually and is named like this:

- b) Follow-up. This tries to observe the problematic scenario, its evolution and apply actions that allow, as far as possible, to solve it.

\section{Types of care}

According to the characterization and the actors of the tutorial action, in the context of the General Baccalaureate two types of attention are considered, which are described below:

Group: In this mode, the teacher responsible for the Tutoring provides accompaniment to all the students in the group during their stay at the campus, based on a pedagogical intention. This modality of tutoring works on topics where treatment is feasible at the group level, such as: study techniques, learning styles, cooperative work, through group actions, conferences or meetings, tests and group techniques, etc.

Individual: This type of care provides support to a student in their training process, because it requires individualized procedures. In this modality, personal interviews are carried out on a frequent basis, since the case is followed up, and if necessary, the student is channeled to the institutional environment that manifests the required professional service.
Peer tutoring: Peer tutoring is defined as a cognitive and motivating interactive teachinglearning process, which, guided by the teacher and based on the subjects of the curriculum, continuously and systematically links different student actors at university levels with their counterparts from previous levels, in an educational strategy for the development of scientific, technical, cultural, psychological and socio-political values in both student actors Menéndez Valera (2010, p.89).

\section{Topics covered by tutoring}

The DGB marks as the main topics to address from the tutoring the following (DGB, 2012):

- Aptitudes.

- Motivation.

- Cognitive habilyties.

- Attention.

- $\quad$ Memory.

- $\quad$ Reading comprehension.

- $\quad$ Time management.

- Diagnosis.

- $\quad$ Auto diagnosis.

- Metacognition.

- $\quad$ Learning styles.

- $\quad$ Study habits.

- $\quad$ Abilities.

- $\quad$ Attitudes.

- $\quad$ Interest Inventory.

- Study Techniques.

\section{Generic skills that the tutoring works}

Holds a position on topics of interest and general relevance, considering other points of view. 
Learn by initiative and self-interest throughout life.

Participate and collaborate effectively on diverse teams.

Participate with a civic and ethical conscience in the life of your community, region, Mexico and the world.

Maintains a respectful attitude towards interculturality and diversity of beliefs, values, ideas and social practices.

Contributes to sustainable development in a critical way, with responsible actions

He knows and appreciates himself and addresses problems and challenges taking into account the objectives he pursues.

He is sensitive to art and participates in the appreciation and interpretation of its expressions in different genres.

Choose and practice healthy lifestyles.

Listens, interprets and emits relevant messages in different contexts through the use of appropriate media, codes and tools.

Develops innovations and proposes solutions to problems based on established methods (DGB, 2012 p. 10).

\section{Methodology}

\section{Kind of investigation}

It is a descriptive quantitative research, as it seeks to describe a situation and is carried out through surveys to measure a specific factor.

\section{Instrument}

It was a survey designed by the coordination of tutorials in order to learn about the topic of interest to be addressed in the following events. Once the pilot version was prepared, we subjected it to a process of validation and experimentation, respectively involving university experts in educational guidance.

\section{Sample}

152 attendees of the Fourth Tutoring Expo were surveyed, through a simple random sample of participants of both sexes.

\section{Results}

According to the results analyzed based on the survey applied to the students, through a simple random sampling that included $76 \%$ of the total attendees to the event. Not all participants suggested topics of interest. Only those topics that had the greatest number of interested parties are those shown in the graphs, highlighting the controversial or relevant topics for society at this time, such as: abortion $18 \%$, sexual avalanche $14 \%$, violence $11 \%$, feminism $11 \%$ Study techniques $11 \%$, Contraceptive methods $11 \%$, Gender equality, $10 \%$ how to be a good tutor and learn, $7 \%$, sexually transmitted infections $7 \%$ It would be interesting to know the reasons why young students focus their attention in these topics to design a comprehensive action plan and thus clear up your doubts that lead us to adequately improve their development.

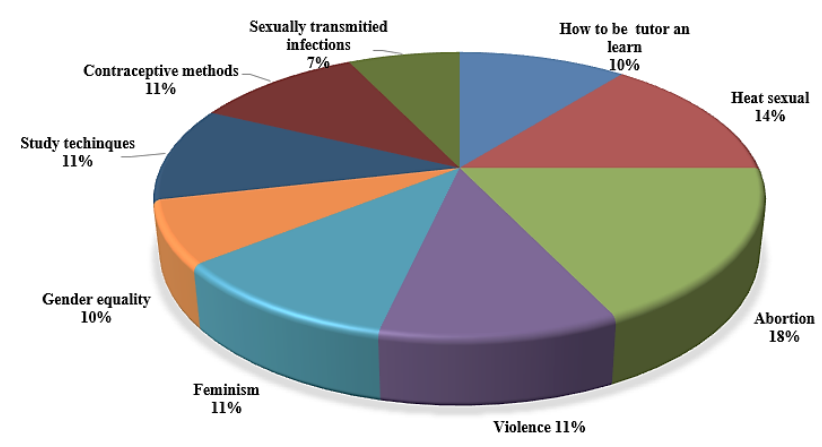

Graphic 1 Topics of greatest interest to students

This can be deduced from the topics that they propose for future training, which, in general, focus on the personal area of the young person, because problems in relation to topics proposed by the students for presentations were abortion, sexual health, how to be a good tutor, violence feminism, study skills, contraceptive methods, gender equality, sexually transmitted infections.

The training and updating of teachers constitute the main axes of a public policy in this area. There are large gaps between the formulation of the programs and the implementation of their contents, related to the leadership of each institution, in general, and to the performance of the teachers, in particular, he concluded. 
On the other hand, humanistic education seeks to attend to the individual integrally taking priorities such as intelligence, behavior and sensitivity, reconsiders the human being as a constructive subject of his practice and appropriate education, because he is reflective of himself and his coexistence to take practices, recognize their actions, opinions and beliefs that allow them to establish the path towards their practice.

The university teacher has enormous challenges and today faces a scenario of change that requires taking an unequal role (Rodríguez, 2002); Not only does he have to be a scholar in his field, an expert in methodologies and, but he also needs to be a guide and reviewer of the student's intellectual formation. It is essential to change the traditional role of teachers to a role of transmitter of knowledge, to achieve the role of organizer and guide of learning, facilitator that constitutes contexts, produces, locates on methods, shows basic research, mentors and values the realization of actions (Álvarez and García, 2002; González and Wagenaar, 2003). University tutoring is registered as a dynamic device of the academic, private and professional pedagogical matter of the student, aimed at training entrepreneurial students who know and manage to constitute their work as independent professionals.

One of the enormous challenges facing university teachers lies in adapting their teaching strategies to the new paradigm established by university education. From this perspective, the benefits of educators in relation to their educational actions will depend, to a large extent, on the familiarity they have in themselves to find all these changes that their new role carries. To conclude, the need to work with teachers and with their own way of selfregulating learning is visualized, since knowing yourself and your own learning processes can benefit you when doing it in the classroom, providing tools and knowledge to to be able to put into practice and promote in their students an active knowledge and a construction of their autonomous learning.
It is up to the professor to optimize the information about what happens at the university, for this reason, it is essential to be linked to national problems, to be aware, albeit in a general way, about the normative and procedural framework that administers the university and that systematizes intellectual and contractual responsibility; for a more harmonious, effective and equitable help commitment. Teaching autonomy is important not to be wasted in personalistic desires and divisions that abandon us from the observance of the mission and, even, from our obligations.

\section{References}

Arbizu, F., Lobato, C., y Del Castillo, 1. (2005). Algunos modelos de abordaje de la tutoría universitaria. Revista de Psicodidáctica, 10(1), 7- 21. Recuperado de http://dialnet.unirioja.es/servlet /articulo?codigo $=1222702$.

Centro de Investigación y Documentación Educativa. (2008). La orientación en la atención a la diversidad; los procesos de enseñanzaaprendizaje y la acción tutorial. En M. Grañeras Pastrana \& A. Parras Laguna (Coords.), Orientación educativa: fundamentos teóricos, modelos institucionales y nuevas perspectivas (pp. 181-224). Madrid: Ministerio de Educación, Política Social y Deporte, Subdirección General de Información y Publicaciones.

De la Cruz, G., García, T. y Abreu, L. (2006). Modelo integrador de la tutoría: de la dirección de tesis a la sociedad del conocimiento. Revista Mexicana de Investigación Educativa, 11(31), 1363-1388. Recuperado de http://dialnet.unirioja.es/servlet/articulo?codigo $=2323338$ DE LA CRUZ FLORES, G.,CHEHAYBARY KURY.

Herrera Aponte, M. (2006). El proceso de tutoría. Un ritual a la esperanza. EDUCARE, 10(3), 192-201. Recuperado de http://revistas.upel.edu.ve/index. php/educare/article/view/145.

Lázaro, A. (1997). La acción tutorial de la función docente universitaria. Revista Complutense de Educación, 8(1), 233-252. Recuperado el 2 de febrero, 2009, de http://www.ucm.es/BUCM/revistas/ edu/11302496/articulos/RCED9797120233A.P DF. 
González, A (2017) La tutoría como eje relevante en la formación de los estudiantes. http://www.comie.org.mx/congreso/memoriaele ctronica/v14/doc/1836.pdf

Menéndez Varela, J. L. El problema terminológico de la tutoría entre iguales y la afirmación de su especificidad didáctica https://web.ua.es/es/ice/documentos/tutorial/ma terial/ivjornada/la-tutoria-entre-iguales.pdf (20/07/2020).

Romo, A. (2011) La tutoría: una estrategia innovadora en el marco de los programas de atención a estudiantes México, D.F.: Asociación Nacional de Universidades e Instituciones de Educación Superior, Dirección de Medios Editoriales, 2011. 123 p. - (Colección Cuadernos Casa ANUIES). 